\title{
Ubuntu feminism: Tentative reflections
}

\begin{tabular}{|c|c|}
\hline \multicolumn{2}{|c|}{$\begin{array}{l}\text { Authors: } \\
\text { Drucilla Cornell }{ }^{1,2} \\
\text { Karin van Marle }\end{array}$} \\
\hline \multicolumn{2}{|c|}{$\begin{array}{l}\text { Affiliations: } \\
{ }^{1} \text { Department of } \\
\text { Jurisprudence, University of } \\
\text { Pretoria, South Africa }\end{array}$} \\
\hline \multicolumn{2}{|c|}{$\begin{array}{l}{ }^{2} \text { Department of Political } \\
\text { Science, Women's Studies, } \\
\text { Comparative Literature } \\
\text { Rutgers, United States }\end{array}$} \\
\hline \multicolumn{2}{|c|}{$\begin{array}{l}{ }^{3} \text { Stellenbosch Institute for } \\
\text { Advanced Study, University of } \\
\text { Stellenbosch, South Africa }\end{array}$} \\
\hline \multicolumn{2}{|c|}{$\begin{array}{l}\text { Correspondence to: } \\
\text { Karin van Marle }\end{array}$} \\
\hline \multicolumn{2}{|c|}{$\begin{array}{l}\text { Email: } \\
\text { karin.vanmarle@up.ac.za }\end{array}$} \\
\hline \multicolumn{2}{|c|}{$\begin{array}{l}\text { Postal address: } \\
\text { Department of } \\
\text { Jurisprudence, Law Building } \\
\text { 2-20, University of Pretoria, } \\
\text { Hatfield } 0002 \text {, South Africa }\end{array}$} \\
\hline \multicolumn{2}{|c|}{$\begin{array}{l}\text { Dates: } \\
\text { Received: } 02 \text { Mar. } 2015 \\
\text { Accepted: } 22 \text { June } 2015 \\
\text { Published: } 21 \text { Aug. } 2015\end{array}$} \\
\hline \multicolumn{2}{|c|}{$\begin{array}{l}\text { How to cite this article: } \\
\text { Cornell, D. \& Van Marle, K., } \\
\text { 2015, 'Ubuntu feminism: } \\
\text { Tentative reflections', Verbum } \\
\text { et Ecclesia } 36(2) \text {, Art. \#1444, } \\
8 \text { pages. http://dx.doi. } \\
\text { org/10.4102/ve.v36i2.1444 }\end{array}$} \\
\hline \multicolumn{2}{|c|}{$\begin{array}{l}\text { Note: } \\
\text { Research Participant in the } \\
\text { Ubuntu-Research project of } \\
\text { the University of Pretoria. }\end{array}$} \\
\hline \multicolumn{2}{|c|}{$\begin{array}{l}\text { Copyright: } \\
\text { (c) 2015. The Authors. } \\
\text { Licensee: AOSIS } \\
\text { OpenJournals. This wor } \\
\text { licensed under the Crea } \\
\text { Commons Attribution } \\
\text { License. }\end{array}$} \\
\hline \multirow{2}{*}{ 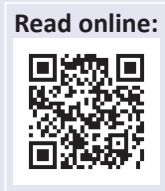 } & \\
\hline & $\begin{array}{l}\text { Scan this QR } \\
\text { code with your } \\
\text { smart phone or } \\
\text { mobile device } \\
\text { to read online. }\end{array}$ \\
\hline
\end{tabular}

The starting-point for the article is to provide a brief background on the Ubuntu Project that Prof. Drucilla Cornell convened in 2003; most notably the interviews conducted in Khayamandi, the support of a sewing collective, and the continued search to launch an Ubuntu Women's Centre. The article will reflect on some of the philosophical underpinnings of ubuntu, whereafter debates in Western feminism will be revisited. Ubuntu feminism is suggested as a possible response to these types of feminisms. The authors support an understanding of ubuntu as critique and ubuntu feminism accordingly as a critical intervention that recalls a politics of refusal. The article ends by raising the importance of thinking about spatiality through ubuntu, and vice versa. It may seem strange to title an article Ubuntu feminism when feminism itself has often been identified as a European or Western idea. But, this article will argue that ubuntu offers conceptions of transindividuality and ways of social belonging that could respond in a meaningful way to some of European feminism's own dilemmas and contradictions. Famously, one of the most intense debates in feminism was between those who defended an ethic of care in a relational view of the self, on one side, and those feminists who held on to more traditional conceptions of justice, placing an emphasis on individuality and autonomy, on the other side. The authors will suggest that ubuntu could address this tension in feminism. Thus, in this article the focus will not simply be on ubuntu, in order to recognise that there are other intellectual heritages worthy of consideration, other than those in Europe and the United States. It will also take a next step in arguing that ubuntu may be a better standpoint entirely from which to continue thinking about what it means to be a human being, as well as how to conceive of the integral interconnection human beings all have with one another. This connection through ubuntu is always sought ethically, and for the authors it underscores what we have both endorsed as ethical feminism. In this essay it is considered how ubuntu feminism could refuse the demands of patriarchy, as well as the confines of liberal feminism. The authors are interested in thinking about ubuntu in general as critique, as a critical response to the pervasiveness of a liberal legal order. Their aim is also to explore tentatively ubuntu and spatiality - how could one understand ubuntu in spatial terms, and more pertinently, how could ubuntu and ubuntu feminism relate to spatial justice? Before turning to the theoretical discussion, some of the on-the-ground history of the Ubuntu Project will be reviewed, including the Project's attempt to build an Ubuntu Women's Centre in Khayamandi in the Western Cape, South Africa.

\section{A brief history of the Ubuntu Project since 2003}

The Ubuntu Project began in 2003 with a small stipend from the Stellenbosch Institute for Advanced Study. At first there was a great deal of scepticism on the part of mainstream white academics about whether ubuntu was actually a value that still held a substantial amount of purchase in the majority black population. As a result the Project began with a series of interviews, the feedback from which, the authors anticipated, would shed some light on the question of whether or not that scepticism was justified. In short summation, the scepticism often turned on misconceived notions, which not only argued that ubuntu is premodern but also that it endorsed old-fashioned hierarchies such as patriarchy. It appeared that these sceptics worried about the very content of ubuntu - but they were not the only kind of sceptics. Other sceptics held that even if ubuntu had once been a powerful value important to the struggle for change in South Africa, it no longer played a major role among young people in the country. Indeed, it was challenged that many of the rituals, such as lobola, were no longer practiced amongst young, urban, black South Africans. In response to this scepticism, Prof. Cornell joined with five young residents of Khayamandi to conduct interviews, discussing whether or not this scepticism was at all justified.

The five interviewers were all lifelong residents of Khayamandi and were deeply connected to the community. What the interviews ultimately showed was that the value of ubuntu remained extremely important; young black South Africans still take the rituals seriously and 
practice them as a way of thinking about our fundamental interconnectedness, as well as a way of living it. The interviews also confirmed that ubuntu was considered to be at the heart of the way the community thought human beings should live their lives. Indeed, ubuntu was conceived by the interviewees as an African principle encapsulating what it means to be human and how all of social relationships are necessarily embedded in an ethical entanglement that begins at birth

These interviews provided helpful sociological insight showing that there was little basis for the scepticism the authors were initially met with; therefore, the importance of ubuntu needed to be promoted amongst all aspects of academic life, not undermined. But, as mentioned above, another one of the objections was that ubuntu was both premodern, as well as patriarchal in the worst sense of the word, as insisting on the authority of men over women. As Justice Ngcobo (Bhe and Others $v$ Khayelitsha Magistrate and Others [CCT 49/03] [2004] ZACC 17) ${ }^{1}$ has argued, there was a time when most Africans were hunters and gatherers. At least hypothetically during this time an African notion of gender trusteeship developed. Under this ideal of trusteeship, women were entitled to certain kinds of care from men, but this kind of trusteeship, for Ngcobo, only made sense in those types of societies. But, the question must be asked if ubuntu can push towards a more egalitarian modality of social relations and away from trusteeship? And, is this what is happening in South Africa now?

As time progressed, the Ubuntu Project became involved in a number of on-the-ground issues that shifted the emphasis from interviews towards activism. From early on, the idea of an Ubuntu Women's Centre was raised. One idea that came out of the meetings was that a collective economic empowerment project should be established, which would offer employment to unemployed women in the township. The idea of a sewing collective was decided on, and with assistance of a sangoma, with whom Prof. Cornell had a close relationship, the Project received sewing machines and other supplies. The idea was that unemployed women would sew 'traditional clothing' that they could sell at an onthe-street marketplace. The sewing collective ran for about a year and some of the women involved were able to earn desperately needed income for both themselves and their families. All profits were shared collectively in line with the principle of ubuntu. The deep sense of collectivity, borne out by the successes of the collective, was used to channel more enthusiasm toward the idea of an Ubuntu Women's Centre.

The initial interviews and the engagement with members of the Khayamandi community left the authors with the conviction that to regard ubuntu as either conservative or fundamentally patriarchal misunderstands the transformative potential of ubuntu. This is not to deny, however, that ubuntu has been deployed for conservative purposes. It is not something that can simply be uncovered. Like all values that claim roots in an indigenous past, that past is also grasped through recollective imagination and the struggle for a better future. This is certainly true in the case of what will later be discussed as revolutionary ubuntu.

\section{The philosophy of ubuntu}

First of all, ubuntu cannot be reduced either to ontology, epistemology, or an ethical value system; that is if one even wanted to speak in this regard in the terms of European philosophy. In a sense ubuntu is all three. That ubuntu can be thought to be inclusive of all three demonstrates how major distinctions in European and Anglo-American philosophy are not replicated in African philosophy more generally. This already indicates how some of the major distinctions in the Anglo and European philosophical traditions are not reducible to European thinking and are not replicated entirely in African philosophy.

Ubuntu is a philosophy on how human beings are intertwined in a world of ethical relations from the moment they are born. Fundamentally, this inscription is part of our finitude. We are born into a language, a kinship group, a tribe, a nation, and a family. We come into a world obligated to others, and those others are obligated to us. We are mutually obligated to support each other on our respective paths to becoming unique and singular persons. In European writing, the philosopher Benedict de Spinoza has often been linked to the idea of transindividuality (Spinoza 2000:X). Indeed, he is seen as one of the only thinkers to underscore transindividuality (Balibar 1998).

This could be related to what Masolo (2004:483-498) has called 'participatory difference'. For Masolo, participatory difference recognises that each one of us is indeed different from all other people. The crucial part of this difference, however, is that we are also called to make a difference by contributing to the creation and sustenance of a human and ethical community. Critics of ubuntu, including those who conflate ubuntu with outdated modes of social cohesion and hierarchies, make the mistake of reducing ubuntu to an ethical ontology of a purportedly shared world. What is missed in the conservative critique is precisely the activism inherent in making a difference. In this manner, ubuntu clearly has an ideal edge. There is no end to the struggle to bring about a human world and to become an individual person who makes a difference within it. The acclaimed South African philosopher, Mabogo P. More (More 2005), brings together different aspects of ubuntu in his profound yet succinct definition:

In one sense, ubuntu is a philosophical concept forming the basis of relationships, especially ethical behavior. In another sense, it is a traditional politico-ideological concept referring to sociopolitical action. As a moral or ethical concept, it is a point of view according to which moral practices are founded exclusively on consideration and enhancement of human wellbeing; a preoccupation with the 'human'. It enjoins that what is morally good is that what brings dignity, respect, contentment, 
and prosperity to others, self, and the community at large. Ubuntu is a demand for a respect for persons no matter what their circumstances may be... In its politico-ideological sense it is a principle for all forms of social or political relationships. It enjoins peace and social harmony by encouraging the practice of sharing in all forms of communal existence. (pp. 156-157)

As an ethical as well as a politico-ideological concept, and one that encompasses categories that are often called ontology and epistemology, ubuntu always entails a social bond. But, one that is always in the course of being shaped and reshaped by the heavy ethical demands it puts on all its participants. And, why ontology and epistemology? As an ontology, ubuntu narrates how human beings are actually intertwined. It is therefore about the being of the human. But, the being of the human also constitutes how we see the world; for this intertwinement is inherently ethical. When we see or grasp the world, we epistemologically understand it through an inherent ethicality that inheres in our human being with inescapable obligations. Furthermore, since it is an ethical one, this social bond is always demanding the rethinking of what the ethical, and therefore, what the politico-ideological demand. Ubuntu in this sense encapsulates how we know the world, as well as how we are in it through the moral obligations as human beings who must live together. It implies the moralisation of all social relations. And, this moralisation of social relations is the one aspect of ubuntu that is unchanging.

\section{The concept of governmentality under ubuntu}

In European philosophy most conceptions of social belonging are either rooted in fear or utility. In Thomas Hobbes it was primarily fear that would lead individuals to relinquish their natural freedom and subordinate themselves to a Leviathan that would protect them from others who would constantly be a threat if there was no law to rule over them. In Kant, by contrast, the contract is inherently moral. And, in a deep sense, there are no individuals in Kant that are selfdetermining. The social contract is hypothetical in so far as it imagines what moral individuals, who subordinated themselves to the moral law, might agree to. Kant's moral person is not an individual in the Hobbesian or utilitarian sense, but even if the social contract is hypothetical in that it entails we project ourselves as moral human beings subordinated to the moral law in the Kingdom of Ends, as if we were already living together in the Kingdom, we can still conceive of social belonging through the social contract. Even though this will be a conception of the social contract that is substantially different from what the Hobbesian one is based on, it is still a conception of the social contract. For ubuntu, the very notion of the social contract misses the idea that human beings are born into an affective network that is constantly being transformed by the participants themselves. The idea, then, of social belonging is one in which the purpose of coming together under the law - or even, say, under the living customary law, the law of the majority of the black population - would always demand that the purpose of any kind of government is to create a world in common and to enhance the publicly shared good. It would not be built out of fear or neutral exchanges in the free marketplace, or even the aesthetic idea of the Kingdom of Ends wherein we would together be acting morally to bring about a just world. It is both more active than that and the purpose is fundamentally different. Thus, ubuntu rejects the pessimistic ideas of human nature that pervade so much of European and Anglo and American political theory. Instead it defends itself as a new way of being human together.

We need to judge ubuntu not simply because it is African or South African, but rather because the philosophical project it offers is one of solidarity building. And, indeed, if one takes revolutionary ubuntu seriously as a project of 'radical transformation', solidarity must be at the core. The phrase revolutionary ubuntu was coined by the Shack Dwellers movement, as well as other movements of the poor in South Africa, who argue that ubuntu itself is an anti-capitalist ideal and that neoliberal capitalism cannot be conceived as consistent with it. Economist Sampie Terreblanche, in his groundbreaking book A History of Inequality in South Africa (Terreblanche 2002), describes 354 years of patterns of unfree black labour to underscore that the transformation in the country cannot move forward unless it completely undoes that history. For Terreblanche, the transformation of South Africa can only take place if the destructive aspects of this long history of unfree black labour, which clearly began long before the institutionalisation of apartheid, is completely reversed. This can only happen if some form of either social democracy or democratic socialism is implemented at the institutional level. But, we can also read unfree black labour as implying a telos that points toward a different history of free human beings living together under ubuntu. It is important to note that the phrase 'unfree black labour' unites both a race and a class; and in addition it points to how the so-called 'modern' project of neoliberal capitalism turns on forms of indentured servitude, which allow for the super exploitation of the large majority of humanity. Within South Africa, Terreblanche's powerful argument is that residues of unfree black labour have completely undermined the transformation of the country. Two points need to be underscored here. First, that ubuntu points towards a conception of what it means to be a free human being who maintains that the human being must be unchained from unfree black labour. And, secondly, there can be no serious transformation of South Africa without thoroughgoing economic transformation. In his book, Lost in Transformation, Terreblanche (2004) pointedly argues that transformation has faltered or indeed failed because of the neoliberal economic policy of the ANC. It failed before what revolutionary ubuntu demands, namely, free individuals living and shaping their future as one that is always open to transformation. (See also in general Cornell 2014).

But, there is another aspect of ubuntu important in this regard; ubuntu necessarily implies the struggle against anti-black racism. Many figures in the history of African philosophy, from Frantz Fanon (1963) to Mabogo P. More (2005), to Lewis Gordon (2006) and many others have all argued that 
the struggle against racism is not only political and ethical, but also philosophical. As stated before, it is philosophical because ubuntu challenges some of the primary distinctions made in Europe and Anglo-American philosophy such as ontology, epistemology, and ethics. But, it does so through the elaboration and narration of a new vision of humanism. To consider ubuntu seriously as a philosophy means to challenge racism. Indeed, it is to challenge the racism that inheres in the critique of racism too vague to have any moral, ethical, or political purchase. The Ubuntu Project, as already indicated, has in a deep sense been both descriptive and prescriptive because the African ideal such as ubuntu could be universalised. To even hypothesize the reach of an African ideal in this manner implies an anti-racist stance that is not neutral, as if such neutrality could ever actually exist in research.

We are interested in thinking about ubuntu as also a form of critique, and maybe even to follow Ranciere (2004:197), as a staging of dissensus. The ethics of ubuntu, as explained above as one of intertwinement with others, challenges in a radical way what is usually seen or accepted as common sense. By way of everyday practices and ordinary lives, traditional liberal assumptions of the self, but also of law, justice and power are thwarted. Mark Sanders (2007:12) argued that ubuntu is an ethics that 'continually marks and remarks a loss of humanity, and of human dignity'. In the context of debates on restoration, Sanders contended that ubuntu will never accept final restoration because it 'resides in a perpetual remarking of default' (2007:120). Ubuntu as critical response would be one that unsettles and opens, rather than unites and confines.

Now, some of the debates within European and AngloAmerican political theory that have historically plagued theoretical feminism will be examined.

\section{Western debates in feminist theory: Why ubuntu may offer a philosophical solution}

Famously, in the United States a debate broke out between feminists who argued for an ideal of justice and other feminists who, after the publication of In a Different Voice (1988) by Carol Gilligan, advocated for the ethics of care. In short summation, the debate went something like this. Feminists who argued for justice as the overarching framework for feminist theory often held on to the notion of the 'autonomous individual' and posited that women have been denied their autonomy. This denial of autonomy was a major ethical and political problem. Even the great thinker, Simone de Beauvoir (1953), argued that the most important goal for women was to overcome the burden of their femininity and to live authentic and free lives, in the existential sense. The ways of thinking associated with femininity, for De Beauvoir, were bogged down by the imposition of gender stereotypes that functioned powerfully to prevent women from claiming their existential freedom. In short, it is no secret that De Beauvoir's work influenced generations of feminism, sometimes implicitly and sometimes explicitly so. For De Beauvoir, feminism began with breaking down or rejecting all the stereotypical lifestyles of the so-called 'good woman'. First and foremost, women should reject marriage, and De Beauvoir particularly attacked the notion of motherhood. With the rejection of all these traditional and so-called 'feminine' lifestyles, new ways of being a free human being unburdened by abject femininity could begin to arise. To embrace being a woman for De Beauvoir, that is, to embrace sexual difference, was to be captured by these myths and stereotypes so forcefully imposed on women. Although many feminists, who saw justice as the ideal to be attained by women in the late 1960s and early 1970s, were not 'De Beauvoirians', existentially speaking, their claim was that men and women were equal in their capacity to live autonomous lives.

According to Gilligan (1988), thinkers like Kohlberg argued that human beings went through stages of moral reasoning. The highest form of moral reasoning for Kohlberg, a type of moral reasoning that he and others associated with Kantian rationality, is the ability to actively abstract things from circumstances of context, and subsequently posit them as universally justifiable moral judgements. Kant himself, and perhaps Kohlberg as well, might reach that stage. But in Kohlberg's empirical work, many men reach stage six wherein they could at least engage in rudimentary if not philosophically elegant ways of making universal judgements based on their abstraction from actual moral situations in all of their contextual embeddedness. Women, according to Kohlberg, became stuck at stage three. And, what is stage three? It is when a person makes moral and ethical judgements not based on abstract and universal reasoning, but rather by looking only at the concrete and contextual situations under which a given problem arose. This sort of thinking for Kohlberg yielded moral judgements that posited, for example, that sometimes it might be right to steal medicine from the pharmacy for your mother, and sometimes it would not be right. This way of thinking for Kohlberg correlated with the difference between women and men. To some degree Gilligan herself also accepted this correlation. And, there has been much ink spilt with respect to the question of to what degree Gilligan actually accepted the correlation. What we want to emphasize is that Gilligan inverted its meaning; she inverted the meaning by asking: What if that way of thinking about ethics was at least equally as good as universal moral codes? And, therefore, A Different Voice claimed that women's moral thinking should be taken seriously as providing humankind with an ethic of care. Gilligan's own claims were rather modest. She at no time argued that an ethic of care should completely displace universal moral thinking, but rather that it should be taken seriously and not degraded simply because it was associated with women. Women's voice of difference, in other words, should finally not only be heard, but more importantly, it should be respected. Many feminists jumped on her argument and proceeded to take it one step further. An ethic of care was indeed better than abstract justice, no matter how conceived, and that women's voice of difference 
should certainly be respected and heeded, but heeded precisely because it offered a better ethic than the one implied by a misreading of Kant and of one of his respected Anglo-American interpreters, the philosopher John Rawls (1971, 1998).

Along with the idea of an ethic of care came a critique of autonomy. Again, not in the Kantian sense, but rather in the sense of self-determination. Human beings are, so the argument went, relational all the way down. We are fragile creatures born of women and we only have a chance to flourish and survive if we understand ourselves as thoroughly interdependent creatures; not ones who in any other way, but in a fantasy, can be self-determining. This relational view of the self was part and parcel of the ethics of care as many feminists embraced it and elaborated on it. In Seyla Benhabib's (1992) groundbreaking book, she tried to define the difference by arguing that sometimes we should make judgements as generalised subjects and other times as a 'situated self'. Meanwhile, Marxist feminists continued to cling strongly to the position that the problem was not difference, or even the development of an ethic of care through respect for women's different voices; the problem instead was about the material inequality brought about by capitalism. They further argued that if De Beauvoir's demand that women simply forsake reproduction as utopian, the entire notion of the reproduction of the human species has to be completely reorganised.

In the late 1970s at a conference in the United States, ironically on De Beauvoir's work, an argument broke out between white and African feminists. The group led by the acclaimed poet and philosopher, Audre Lorde, argued that women of colour feminists were simply being ignored and the questions of anti-black racism and racism against all people of colour had to be confronted if there was to be a meaningful alliance between women of colour and white women (see Lorde 1978). This confrontation led to a major rift within the feminist movement. Moreover, all of the abovementioned debates became contentious. One of the most profound arguments made by women of colour feminists was that even the right to abortion had to be rethought as it existed within the struggle for reproductive freedom that included all the ways in which women of colour, against their will, were forced into being the objects of experiments for birth control testing, as well as often persuaded into signing away their right to have children because of forced sterilisation. This sterilisation often happened to women who depended on welfare (Roberts 1997:X). As stated above, De Beauvoir argued that women must forsake motherhood and marriage in the name of their struggle for existential freedom. The argument made by African American women at the conference was that slavery had taken away from women the ability to marry, as well as to claim their own children. Therefore, they were not burdened by motherhood because the option of motherhood itself was something that had been decisively denied to them. In fact, under slavery, if they gave birth at all they gave birth to 'commodities', not to children. And, these commodities were simply taken away from them.
In the United States it was not until the mid-20th century that interracial marriage was finally allowed and was no longer considered a crime (in South Africa under apartheid it was also a criminal offence). Thus, the argument made by women of colour feminists was that there were no race neutral notions of motherhood, reproductive freedom, or even, of marriage. All of these needed to be combated within the greater context of the struggle against anti-black racism and the struggle for all people of colour. The authors completely accept the criticism of the women of colour and agree that the entire programme of feminism must be informed by antiblack racism and the struggle against racism more generally.

How might ubuntu help us think differently about these debates? First, as we have already argued, to advocate for ubuntu as a philosophically important vision of our human being already demands that we fight against anti-black racism since we are advocating for the philosophical significance of an African ideal or value. Thus, all reform programmes of feminism or womanism must incorporate this struggle against anti-black racism. Both authors call themselves ethical feminists and at the very core of ethical feminism is the struggle against racism and any other form of degradation that throws some below the bar of the so-called ideals of what it means to be human. Thus, ubuntu thinking can help us think differently about how profound it is that feminism must be raised as anti-racist as part of the definition of ethical feminism. Secondly, and as this debate is going in reverse order since the context of revolutionary ubuntu has already been described, it implies a different way of thinking about belonging that contests the notion of neoliberal capitalism and the ideology of radical individualism. As previously argued, in the place of radical individualism, we have an understanding of the human being that is always already intertwined in relations that are ethical. The community however is not something abstract and outside. It is part of who and how we are with others. It is this intertwinement that makes ubuntu transformative as there is always more work to do together in shaping our future. The future in a deep sense is always a collective project. But this does not mean that individuation is not valued in ubuntu. As already argued, individuation is indeed valued, but as individuation, not as individuality. Thus the flourishing of one human being is not separate from the flourishing of all other. And, therefore, in this sense individuation is valued as individuation within the greater context of a collective struggle. The fantasy of a selfcontained and self-determining human being is denied. So, in the sense of the European and Anglo-American debates the self is understood to be relational all the way to the core and yet each individual will have his or her own unique destiny.

In terms of the debates between the relational self and those who defended the self as a self-determining autonomous self, ubuntu could offer a way out of the paradox by positing that people are only individuated through the support of others, but through this support they do ultimately become unique and singular. Here a different way of thinking about justice and care becomes obvious. As is often underscored in the writings on ubuntu in South Africa, ubuntu can justify 
the dignity of all others. It does so through our sameness, but in a very different sense. We are all equal before the contingencies, fragility, and finitude of our human being, and therefore we all need care and support if we are to flourish. But, we cannot flourish under conditions of inequality that deny that sameness. The focus must be on achieving what we can and should build in common so that all of us can flourish, and not on how we should create a world of self-determining and separated individualities. The radical egalitarianism of revolutionary ubuntu and the different sense of what it means to belong together therefore advocates for a very different way of thinking about justice and care. There can be no justice, and therefore no respect for the dignity of all others, under conditions of inequality. The argument here is that each one of us is different in our very singularity, and we would argue that this demands the opening up of space for new modes of symbolising the feminine within sexual difference. At the same time, though, it also recognises the material inequality and oppression of literally millions upon millions of people on this planet, including women and men; this equality must be overcome as we struggle to build a life in common. Anything less would fly in the face of justice. So there is not a contrast between justice and care. Therefore, they do not need to be pitted against one another, but rather held as part and parcel of a new way of thinking about our human being that demands there can be no care without justice, and without justice there will be no future wherein all human beings can claim their sameness and a new vision of how human beings can live together on this earth.

Reference was made to ubuntu as critique above, and in the same vein, ubuntu feminism should be considered as a critical response, as a refusal of not only patriarchy, but also of any notion of a feminism unmodified. The Italian feminist, Adriana Cavarero (1995), retells the story of Penelope. She places her within the realm of refusal and more pertinently within a space of refusal. The weaving room where Penelope weaves during the day and unweaves during the night becomes a space of refusal. This space refuses the traditional roles assigned to women; Penelope weaves and unweaves, but it is situated also outside the world of men. Penelope and the other women claim a space of their own and create their own rhythm, their own time. In the weaving room they find an interrelatedness and create a politics of refusal. Cavarero (1995) writes:

$[B] y$ unraveling and thereby rendering futile what little she has done, she weaves impenetrable time ... by doing and undoing Penelope weaves the threads of a feminine symbolic order from proportionate materials. (p. 14; see also Van Marle 2007)

Penelope is refusing the role given to her by patriarchy, but importantly, her refusal is not a passive act - she weaves and unweaves, does and undoes, which becomes action. Following Hannah Arendt's (1958) distinction between labour, work and action, Penelope is challenging both the traditional demands of labour and work on women. The weaving room becomes a space of political action and speech, but even more it becomes a 'feminine space where women belong to themselves. It displaces the patriarchal order, setting up an impenetrable distance between that order and itself' (Cavarero 1995:23). The authors' contention is that ubuntu feminism could be seen as a refusal in a similar vein. The ideal of a Ubuntu Women's Centre then is also an ideal of a space, and of spatiality, where women can engage in a politics of action and be in a place where they can be 'themselves'.

Part and parcel of women's oppression is the way in which women are linked to notions of home. As mentioned above, of course not all women across race and class for example have a shared experience of home. However, following the work of others, the authors also want to argue for home to be understood in a multiplicity of ways, including the potential for oppression and freedom. Njabulo Ndebele in The cry of Winnie Mandela (2003), in which Penelope has left Odysseus and her home in Greece in exchange for the road, challenges traditional notions of home and women's relation to it. The four black South African women who are the main protagonists in Ndebele's story reflect on how they waited upon their husbands, their men, to return, in vain. Mannete Mofolo, one of the main characters in the novel, articulates what she sees as a resistance, a detachment that women should adopt if they want to protect their freedom. For the authors, this detachment is not in contrast to ubuntu feminism but shows exactly how ubuntu in its relationality also protects singularity. Mannete's resistance to what is expected from her and her detachment stand in the guise of refusal. Mannete, and also the other three characters in Ndebele's novel, could be read through the lens of ubuntu feminism. The South African poet, Antjie Krog, reflecting on the novel notes the centrality of community in the novel and argues that Ndebele 'establish[es] a community of ordinary women' (Krog 2013:264). She shows how Ndebele breaks with the 'classic narrative' of placing the hero/heroine in a central space in his telling of an 'ethical story' of community (Krog 2013:264). For Krog (2013), Ndebele underscores a sense of interconnectedness between Penelope, Sarah Baartman, Winnie and all women:

And to be our fullest selves, and have our 'giftedness' released, we have to accept one another as part of ourselves. Instead of judging and rejecting one another, women should actively, kindly, remove one another from the banishment as aberration a term and a place that we construct when we refuse to care. (p. 266)

The authors turn finally to what is only the start of a reflection on ubuntu, particularly ubuntu feminism in terms of spatiality. Spatiality has become prominent over the past few decades. Many of the writings on spatiality, and in particular the spatial turn, invoke Michel Foucault's 1967 speech in which he described our time as 'the epoch of space' (Tally 2013:11):

The present epoch will perhaps be above all the epoch of space. We are in the epoch of simultaneity: we are in the epoch of juxtaposition, the epoch of near and far, of the side-by-side, of the dispersed. We are at a moment, I believe, when our experience of 
the world is less that of a long life developing through time than that of a network that connects points and intersects with its own skein. (Foucault 1986:22)

We want to consider if and to what extent ubuntu might be another way of thinking about spatiality. The spatial turn is described as to underscore one's 'consciousness of place', meaning 'one's sense of situatedness in space, as well as spatial divisions, partitions, and borders' (Tally 2013:14). 'The spatial turn is thus a turn to the world itself, towards an understanding of our lives as situated in a mobile array of social and spatial relations that, in one way or another, need to be mapped' (Tally 2013:17). Above the authors have drawn on views that describe ubuntu as a philosophy on how human beings are intertwined in a world of ethical relations. This intertwinement invokes spatiality. Interrelatedness and relationality that are inherently part of ubuntu immediately bring forth notions of spatiality. Ubuntu's connectedness with also a spiritual world and the ancestors invoke a certain notion or maybe rather spirit of place, a genius loci. ${ }^{2}$ Many questions of access to land turns on the need for family members to be able to visit the place of burial of deceased family members, which is about much more than visiting a grave, and rather about being in contact with the ancestors in a specific place (see Du Plessis 2008). The authors should note here that their aim is not so much to read ubuntu through spatiality, which might appear as nothing but another way of linking ubuntu to established Western ways of thinking, but rather to reflect also on the notion of spatiality from the perspective of ubuntu.

But what about ubuntu feminism? Feminist geographers have been concerned with spatial politics for many years. Alison Blunt and Gillian Rose (1993) note that for many feminists, patriarchy, by distinguishing between 'feminine' and 'masculine' spaces, also linked them to certain activities. 'Gender difference was ... seen as inscribing spatial difference' (Blunt \& Rose 1993:1). Doreen Massey, in introducing a volume on gender and space, describes space as amongst other things the realm of the dead, simultaneity, multiplicity, place, world and home (Massey 1994, see also Massey 2005). For the authors' purposes of thinking about ubuntu feminism and spatiality, it is important to note the insistence in spatiality theory that spatiality is about and should be viewed by looking at social relations. In investigating the various configurations of social relations, space should be seen also as integral to time. The notion of space-time is also relevant for the authors' contemplation of ubuntu feminism. The ethical aspiration of living together in a shared world and of being embedded in relationships always already imply a certain simultaneity and multiplicity. Feminist spatial theorists have engaged critically with the traditional distinctions between public and private, universal and local, and women's placement with the latter of these pairs. The authors' sense is that ubuntu feminism, as with the debate between care and justice, could bring a new angle to these 2.Our gratitude to Isolde de Villiers who in a conversation with one of the authors raised this point. distinctions in order to challenge and displace them. To the extent that we are all individuated through the support of others, that we are all equal before the contingencies and finitude of our human being, the very distinctions between public and private and the rest are questioned. The possible implications that spatiality could have for of ubuntu feminism and vice versa will have to be unpacked in future work; let us turn for now to the notion of spatial justice.

Andreas Phillippopoulos-Mihalopoulos (2010) describes the radical call for spatial justice as:

... the demand for a plural, emplaced oneness, the firm position of the body in space and the consequent thematization of the world, including the disorientation, the multiplicity of directions, the simultaneity of movement. (p. 199)

In his 2014 work, he elaborates on the notion of spatial justice and puts forward a complex argument inspired by amongst others Spinoza, Nietzsche, Deleuze, Luhman and Derrida. We can in no way be true to the depth of his view here. Phillippopoulos-Mihalopoulos (2014:3) provides a further definition of 'spatial justice as the conflict between bodies that are moved by a desire to occupy the same space at the same time'. Also, 'spatial justice emerges from a movement of withdrawal from the atmosphere' (PhillippopoulosMihalopoulos 2014:6). Significantly, ‘[s]patial justice ... is not a prescribed avenue but merely the possible reorientation of the lawscape according to the bodies that have withdrawn' (Phillippopoulos-Mihalopoulos 2014:6). This take on a development of spatial justice is important for how law and justice are perceived as such, and has implications for our understanding of ubuntu feminism. PhillippopoulosMihalopoulos (2014:175) puts forward an understanding of spatial justice that derives from the lawscape that differs significantly from more traditional concepts like distributive or social justice. 'Unlike distributive or social justice, spatial justice does not involve processes of consensus, rational dialogue, renegotiation of territory, demos, agency, or even identity formation' (Phillippopoulos-Mihalopoulos 2014:175). Spatial justice as a re-articulation of justice relies on the concepts of lawscape and atmosphere. It 'opens-up' the space of conflict between various bodies finding themselves in the lawscape. Spatial justice comes into play when a body withdraws from the atmosphere and returns to the lawscape:

This is the only way in which a body can question the emplacement of itself as well as other bodies: by withdrawing from an atmosphere of fixed positions. At the same time, this is the only way in which law can generate justice: by withdrawing before the demands of justice while retaining its position as the main means in which justice can be achieved. (PhillippopoulosMihalopoulos 2014:175)

It is exactly the notion of withdrawal from fixed positions that relates to the authors' understanding of ubuntu as critique, and ubuntu feminism as a kind of refusal. As with Mannete's detachment, this withdrawal should not be seen as a move to autonomy or passivity, but rather as a way to bring about a rupture to ingrained distinctions and fixed positions. 


\section{Conclusion}

The authors' aim with this article was to think tentatively about ubuntu feminism and how it could respond to some of the debates in Western feminism. It was introduced by recalling some of the work done by the Ubuntu Project since 2003, whereafter some of the philosophical ideas that underpin ubuntu were described. Finally, ubuntu feminism was examined by first revisiting the debate between justice and care, and also offering a possible response to Western feminism by ubuntu feminism. Ubuntu feminism, as ubuntu, was suggested as a form of critique, in other words the understanding of ubuntu is not to invoke a romantic version of the past but rather to reflect on the critical potential of ubuntu and ubuntu feminism to contribute to the present and future. In concluding, the notion of spatiality was invoked and tentative remarks were made on the relation between spatiality and ubuntu, and ubuntu and spatiality. The article ends with a poem from Antjie Krog's volume, Synapse (Krog 2014:43):

the founding principle of gener
the waxy
cufflink of the
orchid the bit-
ter sneeze of quinine
in sacred bark
the peacock's eye-
splashing wifi a-
rea are useful
for survival thence
the concept:
survival of the
fittest
but the earth does not appear
to be one huge conglomeration
of competing
egos
nothing
tears us away
from its
eyeflood

\section{Acknowledgements Competing interests}

The authors declare that they have no financial or personal relationships which may have inappropriately influenced them in writing this article.

\section{Authors' contributions}

D.C. (University of Pretoria), an Extraordinary Professor in the Department of Jurisprudence since 2010, convened the
Ubuntu Project in 2003. K.v.M. (University of Pretoria) has been involved in the Project and has been a close collaborator since its inception. The relationship between ubuntu and feminism has been of importance to both of the authors since the beginning of the Project. This article is an outcome of many discussions, and was jointly written by them.

\section{References}

Arendt, H., 1958, The human condition, University of Chicago Press, Chicago.

Balibar, E., 1998, Spinoza and politics, Verso, London.

Benhabib, S., 1992, Situating the self: Gender community and postmodernism in contemporary ethics, Routledge, New York.

Blunt, A. \& Rose, G., 1993, Feminism and geography. The limits of geographical knowledge, Marston Book Services, Oxford.

Cavarero, A., 1995, In spite of plato: A feminist rewriting of ancient philosophy, Polity Press, Cambridge.

Cornell, D., 2014, Law and revolution in South Africa: Ubuntu, dignity, and the struggle for constitutional transformation, Fordham, New York. http://dx.doi.org/10.5422/ fordham/9780823257577.001.0001

De Beauvoir, S., 1953, The second sex, Knopf, New York.

Du Plessis, L.M., 2008, 'The South African constitution as monument and memorial, and the commemoration of the dead', in R. Christensen \& P. Bobo (eds.), Rechtstheorie in rechtspraktischer Absicht. Freundesgabe zum 70. Geburtstag von Friedrich Muller,/Legal theory in practice. At the celebration of Friedrich Muller's $70^{\text {th }}$ birthday Berlin, Duncker \& Humblot, pp. 189-205.

Fanon, F., 1963, The wretched of the earth, Penguin Books, London.

Foucault, M., 1986, 'Of other spaces', Diacritics 16, 22-27. http://dx.doi. org $/ 10.2307 / 464648$

Gilligan, C., 1988, In a different voice: Psychological theory and women's development, Cambridge, London.

Gordon, L., 2006, Disciplinary decadence: Living thought in trying times, Paradigm Publishers, Boulder.

Krog, A., 2013, 'What the hell is Penelope doing in Winnie's story?', in N. Ndebele (ed.), The cry of Winnie Mandela, pp. 26-267, Picador Africa, Johannesburg.

Krog, A., 2014, Synapse, Human \& Rousseau, Cape Town.

Lorde, A., 1978, Uses of the erotic: The erotic as power, Out \& Out, New York.

Masolo, D.A., 2004, 'Western and African communitarianism: A comparison', in O. Onazi (ed.), African legal theory and contemporary problems, Dordrecht, Martinus Nijhoff, pp. 483-498.

Massey, M., 1994, Space, place and gender, Polity Press, Cambridge.

Massey, M., 2005, For space, Sage, London.

More, M.P., 2005, A companion to African philosophy, Blackwell, London.

Ndebele, N., 2003, The cry of Winnie Mandela, David Philip, Cape Town.

Phillippopoulos-Mihalopoulos, A., 2010, 'Law's spatial turn: Geography, justice and a certain fear of space', Law, Culture and the Humanities 7, 187-202. http://dx.doi. org/10.1177/1743872109355578

Phillippopoulos-Mihalopoulos, A., 2014. Spatial justice: Body, lawscape, atmosphere. London, Routledge.

Ranciere, J., 2004, 'Who is the subject of the rights of man?', South Atlantic Quarterly 103, 297-310. http://dx.doi.org/10.1215/00382876-103-2-3-297

Rawls, J., 1971, A theory of social justice, The Belknap Press, Cambridge.

Rawls, J., 1998, Political liberalism, Columbia University Press, New York.

Roberts, D.E., 1997, Killing the black body: Race, reproduction, and the meaning of liberty, Pantheon, New York.

Sanders, M., 2007, Ambiguities of witnessing, Wits University Press, Johannesburg. Spinoza, B., 2000, Ethics, ed. G.H.R. Parkinson, Oxford University Press, Oxford.

Tally, R.T., 2013, Spatiality, Routledge, New York.

Terreblanche, S., 2002, A history of inequality in South Africa, 1652-2002, University of Natal, Pietermaritzburg.

Terreblanche, S., 2004, Lost in transformation: South Africa's search for a new future since 1986, Tafelberg, Cape Town.

Van Marle, K., 2007, 'Laughter, refusal, friendship: Thoughts on a "Jurisprudence of Generosity"', Stellenbosch Law Review 18, 194-206. 